\title{
Haems and chlorophylls: comparison of function and formation
}

\author{
G A F HENDRY AND O T G JONES
}

From the Department of Biochemistry, The Medical School, University of Bristol, Bristol BS8 1TD

In 1844 Verdeil $^{1}$ reported that acid treatment of chlorophyll or haem yielded apparently similar red compounds; he even postulated that chlorophylls would contain iron. Hoppe-Seyler ${ }^{2}$ confirmed the apparent similarity of acid derivatives of haems and chlorophylls from their light absorption characteristics, a point rather overshadowing the discovery at the same time by McMunn ${ }^{3}$ of cytochromes, another group of haem proteins.

It was the demonstration by Nencki and coworkers ${ }^{45}$ that the degradation of both chlorophylls and haems yielded monopyrroles that led them, in true neo-Darwinian fashion, to postulate a common origin for animals and plants.

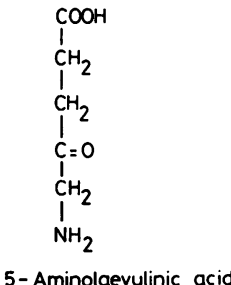

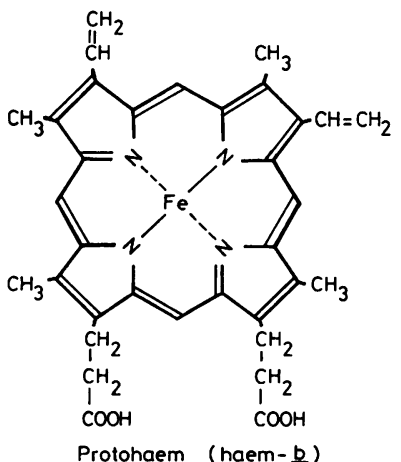

(1)

(2)<smiles></smiles><smiles>[13CH3]</smiles>

(8) $\mathrm{CH}_{3}$

(7) Protoporphyr in IX

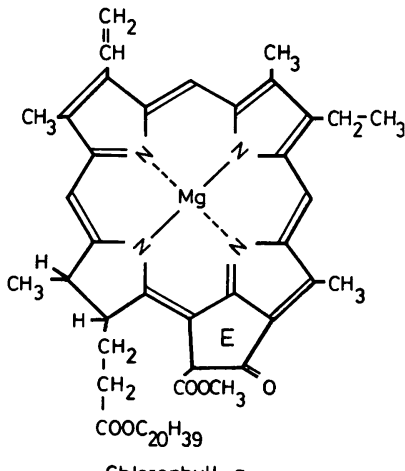

Chlorophyll a
FIG 1 Structures of protohaem and chlorophyll $a$ and two of their precursors, 5-aminolaevulinic acid and protoporphyrin IX (with substituent numbering positions). 
Following the work of Willstätter ${ }^{6}$ and Fischer and Stern, ${ }^{7}$ the structure of most natural and many unnatural porphyrins was established. Although Verdeil's prediction was wrong, he was correct in interpreting chlorophylls and haems as having essentially similar structures.

Today we can show the similarity between haem and chlorophyll based on their common precursor, protoporphyrin IX (fig 1). The carbon numbering system used in fig 1 will be used in the subsequent text.

\section{Natural occurrence of porphyrins}

For over a century, scientists have been aware of the existence of the numerous types of porphyrin-based compounds to be found in a wide range of eukaryotic and prokaryotic organisms. It was presumably only a question of time before reports of extra-terrestrial porphyrins would be made. ${ }^{8}$ The earth-bound biological porphyrins are diverse and range in colour from grey-blue (bacteriochlorophyll), green (chlorophyll), and red (protohaem) to yellow and brown (avian egg porphyrins).

The natural occurrence of many porphyrins is shown in fig 2, together with their biosynthetic relationships. It will be seen that many tetrapyrroles, particularly those of avian egg shells, have no $\stackrel{\mathbb{D}}{\rightarrow}$ central complexed metal. There are only five metals $\underset{\vec{S}}{\vec{S}}$ commonly found in natural porphyrins: copper in a $\frac{7}{0}$ uroporphyrin III derivative in the flight feather of $\frac{C}{0}$ the tropical Musophagidae family of birds; cobalt as $\overline{\bar{\sigma}}$. the metal component of vitamin $B_{12}$ (cobalamins) ${ }^{9}$; $ه$ iron in the metal complex in haems including haemoglobin, myoglobin, catalase, peroxidases, and $\mathrm{c}$ cytochromes. The fourth metal, magnesium, is $\vec{O}$ characteristic of all chlorophylls and bacterio- $\vec{\overrightarrow{ }}$ chlorophylls. A fifth metal, zinc, may complex enzymically or non-enzymically to many porphyrins and to the porphyrin breakdown product biliverdin (it is not known if complexing occurs before or after $\vec{v}$ ring cleavage). Certainly the ease with which zinc is inserted non-enzymically into porphyrins in vitro $\vec{\circ}$ would make it surprising if zinc porphyrins did not exist in vivo. It is indeed more surprising that nature $\vec{T}$ has confined the metal complexes of porphyrins to $\mathbb{D}$ four or five ions only; chemists have been able to insert well over 40 metals into porphyrins.

The biosynthetic pathway (fig 2) of porphyrins from the monopyrrole porphobilinogen begins with $\vec{\odot}$ the formation of the cyclic tetrapyrrole uropor-. phyrinogen isomers III and I. Isomers II and IV have not been reported in biology; isomer $I$ is not an intermediate in haem and chlorophyll synthesis, it

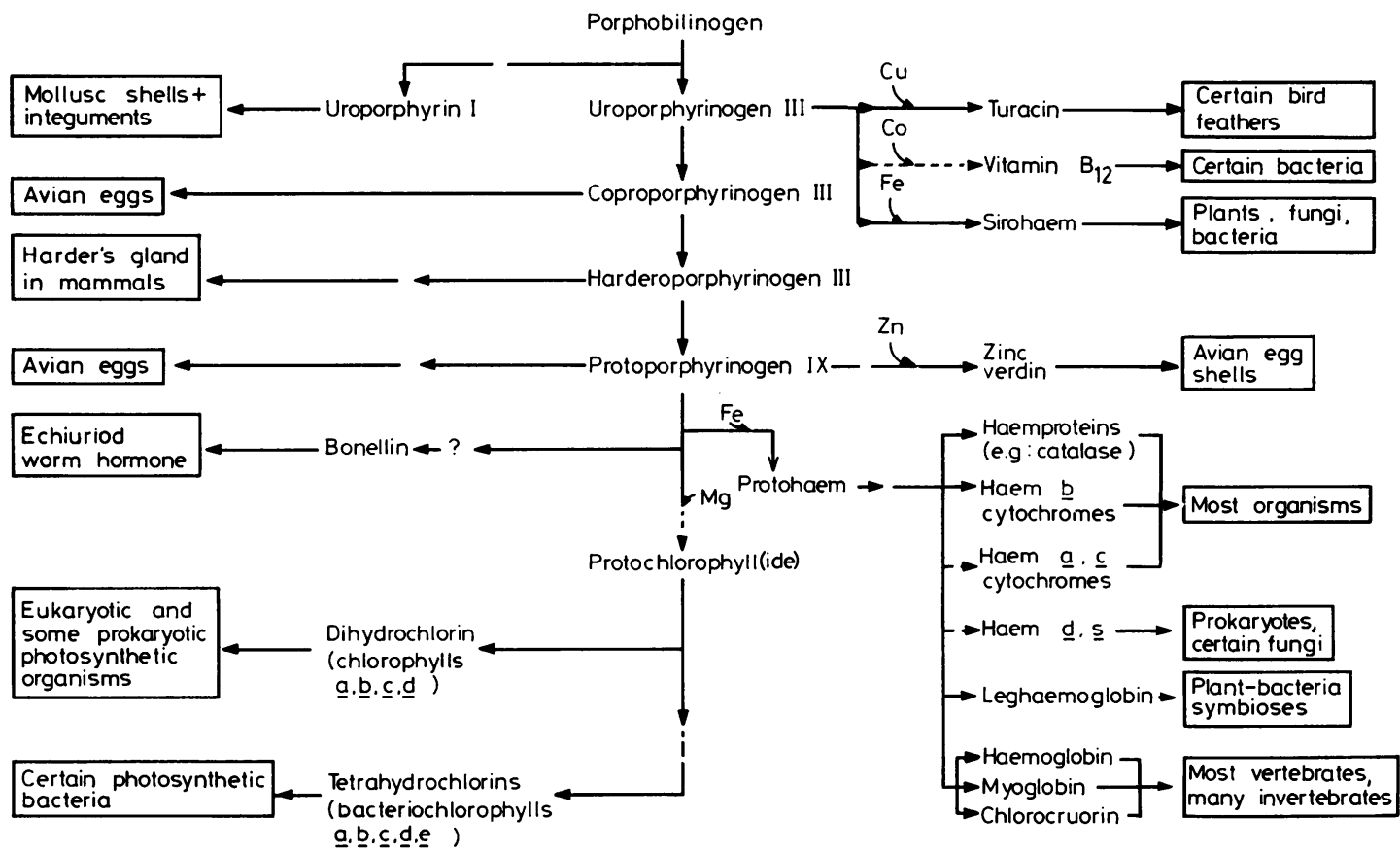

FIG 2 Biosynthetic pathway of tetrapyrroles and their natural occurrence. 
occurs commonly as an excreted compound in the group of disorders of haem synthesis known as the porphyrias. It also occurs in many mollusc shells and integuments, in just those molluscs which do not synthesise haemoglobin. This led Kennedy ${ }^{10}$ to postulate that molluscs themselves may be porphyriacs! These molluscs must additionally make sufficient isomer III for the synthesis of cytochrome prosthetic groups. Uroporphyrin, coproporphyrin, and protoporphyrin are found in egg shells and in some cases account for their characteristic colours. Intermediate between coproporphyrin and protoporphyrin is harderoporphyrin, which is a pigment found in the Harderian gland of the rodent eye, though it is present in other tissues.

A plant equivalent to the porphyric mammal may be found in some $x$-ray or UV treated seedling mutants. Some such seedlings accumulate uroporphyrin, coproporphyrin, and particularly protoporphyrin IX. From such findings protoporphyrin IX has come to be placed in a central role in the study of haem and chlorophyll metabolism. Protoporphyrin isomer IX, of the fifteen possible isomers, is believed to be a prccursor at the branch point of biosynthesis of both haems and chlorophylls.

\section{Naturally occurring iron porphyrins}

From fig 2 it will be seen that a minor pathway may lead to the iron-chelate sirohaem (see below) and a major pathway gives rise to a series of haem compounds, of which the cytochromes, in one form or another, are present in nearly all organisms. Haemoglobin, a characteristic pigment of vertebrates, is present in a wide range of organisms. One family of vertebrates, however, the ice-fish (Chaenicthyidae) survive in the cold waters of the Antarctic apparently without any haemoglobin; their oxygen requirement is met from oxygen dissolved in blood plasma. Similarly, the Leptocephalus eel larva has no haemoglobin until it reaches the elver stage. ${ }^{11} \mathrm{~A}$ form of haemoglobin is found in plants under the name of leghaemoglobin, It is, however, confined to those plants which are able to fix nitrogen in co-operation with the bacterium Rhizobium. Such plants include the legume family. Leghaemoglobin appears to help to maintain a constant, but low, level of oxygen within nitrogen fixing cells. Haem synthesis appears to take place in the bacteria, globin in the plant, the completed molecule being located on the interface of the two organisms. ${ }^{12}$

Plants do not, of course, have a complex gas transport system; they obtain their oxygen from solution in cell wall water films. Haemoglobin is also found in the invertebrate phyla, though in some cases, particularly in parasites such as Aplaniptera (fleas),
Anoplura (sucking lice), and Ixodes (ticks), the haemoglobin is derived from the higher animal, ho and the protein moiety used in nutrition. Full revews of the occurrence of haemoglobins and myogtobin in invertebrates are provided by Kennedy. ${ }^{13}$ The following summary is very much a simplification of what is a complex story. Haemoglobins have been reported in certain protozoan strains, in the larvae of the insect Chironomus, in one sub-class of molluscs, the bivalvia (Solen, Arca, and Pentunaulus where the haemoglobin is present in corpuscles), and in one gastropod genus Planorbis (as free haemoglobin in the plasma). In the crustacea, haemoglobin appears sporadically in all orders of the branchiopods. The most unusual case occurs in Daphnia, where the haemoglobin is generally present in the eggs, but may be absent in the adult. Many crustaceans also contain bile pigments, which by analogy with mammals are, probably, breakdown products of protohaem. Among the nemerteans haemoglobin is present in some members but not all, published phyllogenies showing little correlation with presence or absence of haemoglobin. Haemoglobin is more common in the annelid worms, generally as a freely dispersed pigment. However, in a few species, erythrocyte corpuscles may be found (for example in Travisia and Trevella spp). In the polychaete Aphrodita, haemoglobin is present in the nerve cord.

Among the marine worm phyla, haemoglobin is present in the echiurids and lophophorates, generally within corpuscles. In that 20 th century discovery, the deep sea dwelling pogonophora worms, haemoglobin has been reported, but in a freely dispersed form. It is towards the top of the invertebrate 'tree', the holothurian echinoderms or sea cucumbers, that discoid cells containing haemoglobin are found, corresponding to the erythrocytes of mammals.

The monomer myoglobin is closely related in conformation to one of the chains of the haemoglobin tetramer. It is present throughout the vertebrates but appears only sporadically in the invertebrates. Typically, myoglobin is present in the gastropod radula muscles and the body wall muscles of various polychaete fanworms and occasionally in other phyla.

Haem $s$ (also called Spirographis haem or chlorocruorohaem) in combination with a protein serves as the extra-corpuscular oxygen-carrying pigment in four families of polychaete worms (Sabellidae, Serpullidae, Ampharetidae, and Flabelligeridae). Almost on a belt-and-braces principle, members of the Serpula and Potamilla families contain both haem $s$ protein and haemoglobin. To show complete inconsistency, at least to reviewers, in the family Spirorbis there are three groups, one containing haem $s$ protein, one containing haemoglobin, and the third containing neither. 
Other pigments commonly used in oxygen carrying, other than blood plasma or water, include the iron protein hemerythrin (despite its name not a haem protein) and the copper containing protein hemocyanin (also not a haem protein). The former has a restricted distribution among certain peanut worms, inarticulate brachiopods, and a few other phyla, always apparently in corpuscles. Hemocyanins, as oligomeric proteins, on the other hand are always free floating and are found in the nonhaemoglobin containing molluscs, notably the Prosobranchia and Pulmonata, and in those supposedly ancient mollusc ancestors, the chitons. These hemocyanin containing molluscs accumulate uroporphyrins in their shells. Hemocyanins are also found in scorpions, in the cephalopods (squids, cuttlefish, and octopods), and in the majority of crustaceans, including the malacostracan crabs, lobsters, and shrimps. Hemocyanins are also found in that other living fossil, the survivor of the trilobites, the horse-shoe crab. It is quite clear, then, that alternative systems to haemoglobin for oxygen transport have existed for hundreds of millions of years, probably long before the appearance of the first land animals.

Apart from the animal kingdom, all fungi and plants contain haem pigments, the cytochromes. One third or more of the total tetrapyrrole content of dark-grown barley seedlings consists of protohaem. ${ }^{14}$ Plants, in common with most other organisms, also contain other haem proteins, notably catalase, peroxidases, and tryptophan pyrrolase.

\section{Naturally occurring magnesium porphyrins}

All chlorophylls are magnesium tetrapyrroles and it is likely that they are formed by successive modifications of magnesium protoporphyrin (see Jones ${ }^{15}$ for a discussion of this). Indeed magnesium protoporphyrin and its monomethyl ester have been found in mutant algae, plants, and bacteria in which normal chlorophyll synthesis is inhibited, wholly or in part. A much more commonly found magnesium tetrapyrrole intermediate in cholorophyll synthesis is protochlorophyllide (see fig 3 ), in which the vinyl group at position 4 is reduced to the ethyl, and the fifth ring $\mathrm{E}$, characteristic of the chlorophylls, has been formed by a modification of the propionic acid substituent at position 6 . In higher plants (the flowering plants or angiosperms), the porphyrin protochlorophyllide accumulates if seedlings are germinated in the dark. In most other plants (some algae being an exception) chlorophyll is formed even in the dark, with no detectable protochlorophyllide accumulation. However, protochlorophyllide is an intermediate in the biosynthesis of two classes of

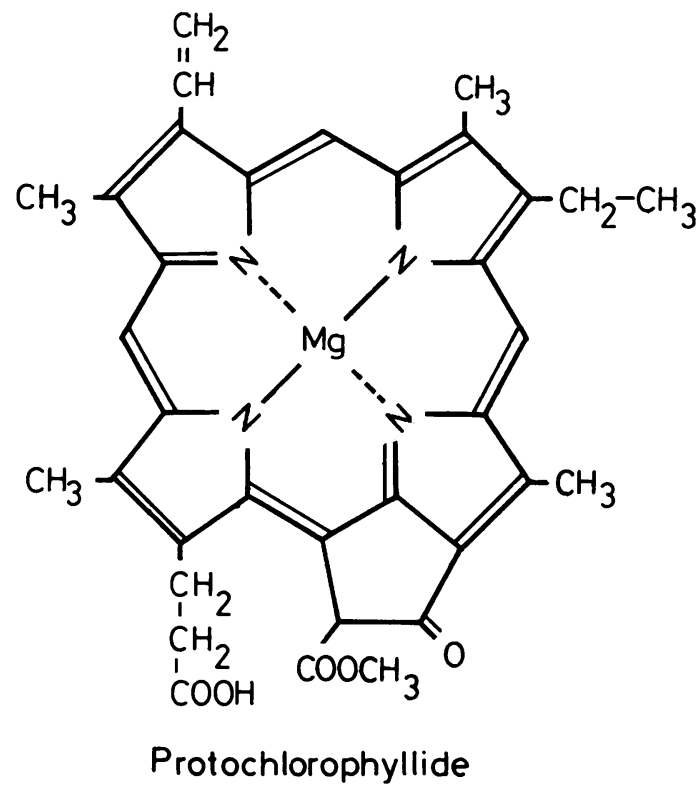

FIG 3 Structure of protochlorophyllide, the precursor of chlorophylls and bacteriophylls.

chlorophyll: the dihydroporphyrins or chlorins (for $\frac{2}{\not}$

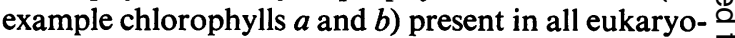
tic photosynthetic organisms and some prokaryotes $\overrightarrow{\vec{O}}$ (the blue-green algae), and the tetrahydroporphyrins 3 (for example bacteriochlorophylls $a$ and $b$ ) found in the purple sulphur (Thiobacteriaceae) and nonsulphur bacteria (Athiobacteriaceae). In the green photosynthetic bacteria (Chlorobiaceae) bacteriochlorophyll $a$ is a minor component; the major $\frac{5}{3}$ chlorophylls are bacteriochlorophylls $c$ and $d$ which are chlorins.

\section{Structures of naturally occurring porphyrins}

Table 1 lists, in an abbreviated form, the major and most of the known minor porphyrins (or porphyrin $N$ derivatives) found throughout the biological world. The salient points from this table are that of the four possible uroporphyrinogen isomers, only isomer III $\mathrm{C}$ is used in haem and chlorophyll synthesis; of the fifteen possible isomers of protoporphyrin, only isomer IX has been reported from biological $\mathbb{D}$ systems. There is a restricted number of side chain $\stackrel{?}{-}$ modifications in naturally occurring porphyrins. $\frac{0}{3}$ Once coproporphyrin III is formed, no further modification occurs at carbon position 1 in any $\stackrel{\odot}{\stackrel{\oplus}{8}}$ organism. Similarly, at carbon position 3, a methyl $\stackrel{\square}{\square}$ group is present in all biological systems (except in $\underset{2}{\sigma}$ 
TABLE 1 Structures of naturally occurring porphyrins

\begin{tabular}{|c|c|c|c|c|c|c|c|c|c|}
\hline \multirow[t]{2}{*}{ Porphyrin } & \multicolumn{8}{|c|}{ Peripheral carbon position } & \multirow{2}{*}{$\begin{array}{l}\text { Complexed } \\
\text { metal }\end{array}$} \\
\hline & 1 & 2 & 3 & 4 & 5 & 6 & 7 & 8 & \\
\hline Uroporphyrin I & Ac & Pr & Ac & Pr & Ac & Pr & Ac & Pr & 一 \\
\hline Uroporphyrin III & Ac & Pr & Ac & Pr & Ac & $\mathrm{Pr}$ & Pr & Ac & - \\
\hline Sirohaem $\ddagger$ & $\mathrm{Ac} / \mathrm{Me}$ & $\operatorname{Pr} / \mathbf{H}$ & $\mathbf{A c} / \mathbf{M e}$ & $\mathrm{Pr} / \mathrm{H}$ & Ac & $\mathbf{P r}$ & Pr & Ac & $\mathrm{Fe}$ \\
\hline Coproporphyrin III & $\mathrm{Me}$ & Pr & $\mathrm{Me}$ & Pr & $\mathrm{Me}$ & $\mathbf{P r}$ & Pr & $\mathbf{M e}$ & - \\
\hline Harderoporphyrin III & $\mathbf{M e}$ & $\mathrm{Vi}$ & $\mathbf{M e}$ & $\mathbf{P r}$ & $\mathrm{Me}$ & $\mathrm{Pr}$ & Pr & $\mathbf{M e}$ & - \\
\hline Protoporphyrin IX & $\mathbf{M e}$ & $\mathrm{Vi}$ & $\mathbf{M e}$ & $\mathrm{Vi}$ & $\mathrm{Me}$ & Pr & $\mathbf{P r}$ & $\mathrm{Me}$ & - \\
\hline Bonellin & $\leftarrow \mathbf{M e}$ & $\mathbf{H}$ & $\mathbf{M e}$ & $\mathbf{H}$ & $\mathbf{M e}$ & Pr & $\mathrm{Pr} / \mathrm{H}$ & $\mathbf{M e} / \mathbf{M e}$ & - \\
\hline Protohaem (haem $b$ ) & $\mathbf{M e}$ & Vi & $\mathrm{Me}$ & $\mathrm{Vi}$ & $\mathrm{Me}$ & Pr & $\mathrm{Pr}$ & $\mathrm{Me}$ & $\mathbf{F e}$ \\
\hline Haem $a$ & $\mathrm{Me}$ & R1 & $\mathbf{M e}$ & Vi & $\mathrm{Me}$ & Pr & Pr & Fo & $\mathrm{Fe}$ \\
\hline Haem $c$ & $\mathrm{Me}$ & $\mathbf{R 2}$ & $\mathbf{M e}$ & $\mathbf{R} 2$ & $\mathrm{Me}$ & $\mathrm{Pr}$ & $\mathbf{P r}$ & $\mathrm{Me}$ & $\mathrm{Fe}$ \\
\hline Haem $d \ddagger$ & $\mathbf{M e}$ & HO-Et & $\mathrm{Me}$ & $\mathrm{Vi}$ & $\mathbf{M e}$ & Pr & $\mathrm{Pr} / \mathrm{H}$ & $\mathbf{M e} / \mathbf{H}$ & $\mathrm{Fe}$ \\
\hline Haem $s$ & $\mathrm{Me}$ & Fo & $\mathrm{Me}$ & $\mathrm{Vi}$ & $\mathrm{Me}$ & $\mathrm{Pr}$ & Pr & $\mathrm{Me}$ & $\mathrm{Fe}$ \\
\hline Lactoperoxidase haem $\ddagger$ & $\mathrm{Me}$ & $\mathbf{V i}$ & $\mathbf{M e}$ & $\mathrm{Vi}$ & HO-Me & $\mathbf{P r}$ & $\mathbf{P r}$ & HO-Me & $\mathrm{Fe}$ \\
\hline Myeloperoxidase haem $\ddagger$ & $\mathbf{M e}$ & $\mathbf{V i}$ & $\mathbf{M e}$ & Vi & $\mathrm{Me}$ & $\mathbf{P r}$ & Pr & Fo & $\mathrm{Fe}$ \\
\hline Mg-protoporphyrin & $\mathbf{M e}$ & $\mathbf{V i}$ & $\mathbf{M e}$ & Vi & $\mathbf{M e}$ & $\operatorname{Pr}$ & $\mathrm{Pr}$ & $\mathrm{Me}$ & $\mathbf{M g}$ \\
\hline Chlorophyllide $a$ & $\mathrm{Me}$ & $\mathbf{V i}$ & $\mathrm{Me}$ & Et & Me & $\mathbf{C P}$ & $\mathrm{Pr} / \mathrm{H}$ & $\mathbf{M e} / \mathrm{H}$ & $\mathbf{M g}$ \\
\hline Chlorophyll $a$ & $\mathrm{Me}$ & Vi & $\mathrm{Me}$ & Et & $\mathbf{M e}$ & CP & Phy/H & $\mathrm{Me} / \mathrm{H}$ & $\mathbf{M g}$ \\
\hline Chlorophyll $b$ & $\mathrm{Me}$ & $\mathbf{V i}$ & Fo & Et & $\mathrm{Me}$ & CP & Phy/H & $\mathrm{Me} / \mathrm{H}$ & $\mathbf{M g}$ \\
\hline Chlorophyll $c 1$ & $\mathrm{Me}$ & $\mathrm{Vi}$ & $\mathrm{Me}$ & Et & $\mathrm{Me}$ & CP & Acr & $\mathrm{Me}$ & $\mathbf{M g}$ \\
\hline Chlorophyll $c 2$ & $\mathrm{Me}$ & $\mathbf{V i}$ & $\mathbf{M e}$ & Vi & $\mathrm{Me}$ & $\mathbf{C P}$ & Acr & $\mathrm{Me}$ & $\mathbf{M g}$ \\
\hline Chlorophyll $d$ & $\mathrm{Me}$ & Fo & $\mathbf{M e}$ & Et & $\mathrm{Me}$ & $\mathrm{CP}$ & Phy/H & $\mathrm{Me} / \mathrm{H}$ & $\mathbf{M g}$ \\
\hline Bacteriochlorophyll $a$ & $\mathrm{Me}$ & R4 & $\mathbf{M e} / \mathbf{H}$ & Et/H & $\mathbf{M e}$ & $\mathrm{CP}$ & $\mathbf{P h y} / \mathbf{H} \dagger$ & $\mathbf{M e} / \mathbf{H}$ & $\mathbf{M g}$ \\
\hline Bacteriochlorophyll $b$ & $\mathrm{Me}$ & R4 & $\mathrm{Me} / \mathrm{H}$ & R5 & $\mathbf{M e}$ & $\mathrm{CP}$ & Phy/H $\dagger$ & $\mathbf{M e} / \mathbf{H}$ & $\mathbf{M g}$ \\
\hline Bacteriochlorophyll $c^{*}$ & $\mathrm{Me}$ & HO-Et & $\mathrm{Me}$ & R6 & $\mathrm{Me}$ or $\mathrm{Et}$ & $\mathbf{C P}$ & Far/H & $\mathbf{M e} / \mathbf{H}$ & $\mathbf{M g}$ \\
\hline Bacteriochlorophyll $d$ & $\mathrm{Me}$ & HO-Et & $\mathbf{M e}$ & R6 & $\mathrm{Me}$ or $\mathrm{Et}$ & $\mathbf{C P}$ & Far/H & $\mathrm{Me} / \mathrm{H}$ & $\mathbf{M g}$ \\
\hline Bacteriochlorophyll $e^{*}$ & $\mathrm{Me}$ & HO-Et & Fo & R6 & Et & $\mathbf{C P}$ & Far/H & $\mathbf{M e} / \mathbf{H}$ & $\mathbf{M g}$ \\
\hline
\end{tabular}

Abbreviations: Ac, $-\mathrm{CH}_{2}-\mathrm{COOH} ; \mathrm{Pr},-\mathrm{CH}_{2}-\mathrm{CH}_{2}-\mathrm{COOH} ; \mathrm{Me},-\mathrm{CH}_{3}$; $\mathrm{Vi},-\mathrm{CH}=\mathrm{CH}$; $\mathrm{Fo},-\mathrm{CHO} ; \mathrm{HO}-\mathrm{Et},-\mathrm{CHOH}-\mathrm{CH}$; $\mathrm{HO}-\mathrm{Me}$, $-\mathrm{CH}_{2} \mathrm{OH}$; Et, $-\mathrm{CH}_{2}-\mathrm{CH}_{3} ; \mathrm{CP}$, - cyclopentanone ring E; Phy, - Pr-phytol ester; Far, $-\mathrm{Pr}-\mathrm{farnesol}$ ester; Acr, $-\mathrm{CH}=\mathrm{CH}-\mathrm{COOH}$; $\mathrm{R} 1,-\mathrm{CHOH}-\mathrm{CH}_{2}-\left(\mathrm{CH}_{2}-\mathrm{CH}=\mathrm{C}_{\mathrm{CH}} \mathrm{CH}_{3}-\mathrm{CH}_{2}\right)_{3}-\mathrm{H} ; \mathrm{R2},-\mathrm{CH} . \mathrm{S}$ Cys. $\mathrm{CH}_{3} ; \mathrm{R3},-\mathrm{Pr}-\mathrm{Me}$ ester; R4, $-\mathrm{C}=\mathrm{O} . \mathrm{CH} \mathrm{H}_{3} ; \mathrm{R} 5,=\mathrm{CH}-\mathrm{CH}$; R6, - propyl, butyl, or ethyl.

* $\delta$-position - ethyl or methyl; + or Pr-geranylgeraniol ester; $\ddagger$ proposed structure.

chlorophyll $b$ ). Another conservative group is at position 5 which always retains the methyl group except in the somewhat uncommon green-sulphur bacteria Chlorobacteriaceae, where the bacteriochlorophylls $c$ and $d$ often include an ethyl group; the haem of the enzyme lactoperoxidase also has an $\alpha$-hydroxymethyl group at this position. Position 8 commonly retains a methyl group except in haem $a$ and myeloperoxidase where a formyl substitution is present and in lactoperoxidase where again the $\alpha$-hydroxymethyl substitution takes place.

So of the eight side group positions found in coproporphyrin III, positions $1,3,5$, and 8 undergo little or no further change. Even among the remaining groups the changes are modest. The ironcontaining porphyrins retain the two propionic acid side chains at positions 6 and 7. Among the magnesium porphyrins, positions 6 and 7 undergo modification; the propionic acid group at 6 , after esterification, forms the characteristic fifth ring $E$. The propionate group at position 7 is esterified also, but with the long chain fatty acid phytol (occasionally farnesol or geranyl-geraniol). Exceptions occur in the case of the $c$ chlorophylls from the brown seaweeds where the propionate group at 7 is oxidised to acrylate.
The most varied substituents in biological systems are found at positions 2 and 4. At position 2, the vinyl groups of protoporphyrin IX are retained in protohaem, the chlorophylls $a$ and $b$, in lacto- and myeloperoxidase. In the iron porphyrins the variation in the position 2 substituents is considerable, from the simple reduction in bonellin (a worm sex hormone) to the long chain 1-hydroxy-2-(E,Efarnesyl)-ethyl group substitution found in haem $a$ (the prosthetic group of the cytochromes $a$ ). Among the chlorophylls, position 2 changes occur in red seaweeds (chlorophyll $d$ ) with formyl substitution for the vinyl group. In the prokaryote bacteriochlorophylls $a$ and $b$, position 2 is modified to form a keto group; in bacteriocholorophylls $c, d$, and $e$, it undergoes hydration to hydroxyethyl groups.

Among the iron porphyrins the substituent at position 4 is fairly constant. The original vinyl group persists in haemoglobin, cytochromes $a, b$, and $d$, catalase, and most peroxidases. Only haem $c$, covalently bonded to its protein to form cytochrome $c$, has thio-ether groups at positions 2 and 4 linking it to the protein. Among the magnesium porphyrins, position 4 modifications are more common. The original vinyl group at position 4 of protoporphyrin IX is reduced to the ethyl state in chlorophylls $a, b$, 
TABLE 2 Structures of naturally occurring compounds derived from or related to porphyrins

\begin{tabular}{|c|c|c|c|c|c|c|c|c|}
\hline \multirow[t]{2}{*}{ Product } & \multicolumn{8}{|c|}{ Original porphyrin carbon position } \\
\hline & 1 & 2 & 3 & 4 & 5 & 6 & 7 & 8 \\
\hline $\begin{array}{l}\text { [Protoporphyrin IX] } \\
\text { Biliverdin/bilirubin } \\
\text { Phycocyanobilin } \\
\text { Phycoerythrobilin } \\
\text { Phytochrome (proposed) } \\
\text { Phylloerythrin }\end{array}$ & $\begin{array}{l}\mathrm{Me} \\
\mathrm{Me} \\
\mathrm{Me} \\
\mathrm{Me} \\
\mathrm{Me} \\
\mathrm{Me}\end{array}$ & $\begin{array}{l}\mathrm{Vi} \\
\mathrm{Vi} \\
\mathrm{Et} \\
\mathrm{Vi} \\
\mathrm{Vi} \\
\mathrm{Et}\end{array}$ & $\begin{array}{l}\mathrm{Me} \\
\mathrm{Me} \\
\mathrm{Me} / \mathrm{H} \\
\mathrm{Me} / \mathrm{H} \\
\mathrm{Me} / \mathrm{H} \\
\mathrm{Me}\end{array}$ & $\begin{array}{l}\text { Vi } \\
\text { Vi } \\
\text { R1 } \\
\text { R1 } \\
\text { R2 } \\
\text { Et }\end{array}$ & $\begin{array}{l}\mathrm{Me} \\
\mathrm{Me} \\
\mathrm{Me} \\
\mathrm{Me} \\
\mathrm{Me} \\
\mathrm{Me}\end{array}$ & $\begin{array}{l}\text { Pr } \\
\text { Pr } \\
\text { Pr } \\
\text { Pr } \\
\text { Pr } \\
\text { CP }\end{array}$ & $\begin{array}{l}\mathrm{Pr} \\
\mathrm{Pr} \\
\mathrm{Pr} \\
\mathrm{Pr} \\
\mathrm{R} 3 \\
\mathrm{Pr}\end{array}$ & $\begin{array}{l}\mathrm{Me} \\
\mathrm{Me} \\
\mathrm{Me} \\
\mathrm{Me} \\
\mathrm{Me} \\
\mathrm{Me}\end{array}$ \\
\hline
\end{tabular}

Abbreviations as for table 1 except for $\mathrm{R} 1,=\mathrm{CH}-\mathrm{CH}_{3} ; \mathrm{R} 2,=\mathrm{CH}-\mathrm{CH}_{3}$.protein; $\mathrm{R} 3,-\mathrm{CH}_{2}-\mathrm{CH}_{2}-\mathrm{CO}_{\text {.protein. }}$

$c$, and $d$ and in bacteriochlorophyll $a$. In bacteriochlorophylls from the green sulphur bacteria, ethyl, propyl, or even isobutyl groups may be present depending on the species involved. Side chain variation among the porphyrin derivatives is for the greater part confined to positions 2 and 4 (table 2).

Certain degradation products of porphyrins are well known. ${ }^{16-18}$ Such products, usually bilins or bile pigments, are listed in table 2. The structural similarity between biliverdin, bilirubin, and mesobilirubin suggests that these compounds are derived from the breakdown of protohaem (from haemoglobin, myoglobin, cytochrome P-450, and cytochrome $b$ ) and this has been confirmed in vitro. The prokaryote blue-green algae and the eukaryote red algae contain bile pigments (probably as accessory pigments in photosynthesis), two of which have been named phycocyanobilin and phycoerythrobilin. ${ }^{19}$ The absence of the fifth ring $E$ and the presence of the propionate group at position 7 suggests that these compounds were derived from protohaem or protoporphyrin and not chlorophyll. The hormone phytochrome is the only bile pigment known in higher plants and it too would appear from its structure $^{20}$ to be a protohaem or a protoporphyrin derivative. There are many reports of bilins and related compounds whose structures have not been defined. Most are assumed to be $\alpha$-IX isomers, ${ }^{21}$ that is the tetrapyrrole ring has been split at the $\alpha$ carbon atom, but at least one case of $\gamma$-IX isomer formation is known from the pigment of butterflies. ${ }^{18}$ Some of the bile pigments so far uncharacterised may be derived from haems $a, c$, and $d$ and perhaps coproporphyrin and protoporphyrin, although alternative haem breakdown pathways have been suggested. ${ }^{22}$ The other interesting point to emerge from studies of naturally occurring porphyrin structures is the absence of any reports of bile pigments derived from chlorophylls. Indeed it is not known how chlorophylls are degraded in vivo. Chlorophyll degradation might involve the loss of magnesium (to form phaeophytin) and the removal of the phytol side chain (to form phaeophorbide). Such compounds have been found generally in trace amounts in autumn senescing leaves. ${ }^{23}$ One of the great mysteries of porphyrin biochemistry is the natural fate of chlorophylls in autumn leaves. Some $10^{12}$ tonnes $^{24}$ of chlorophyll disappear annually, much of it during autumn.

\section{Biosynthesis of porphyrins}

If animals and plants share a common evolutionary origin then it is likely that they would share a common biosynthetic pathway leading to tetrapyrroles, at least in the initial stages of synthesis. If there were major dissimilarities in biosynthesis, then it may be that a form of biochemical convergent evolution has taken place. As will be seen, a study of porphyrin biosynthesis raises some unanswered questions.

Probably all animal haems, vitamin $B_{12}$, and avian egg shell pigments, are derived ultimately from the condensation of glycine and succinyl CoA to form the amino-acid 5-aminolaevulinic acid (ALA, fig 1) (see Bogorad ${ }^{25}$ for a review). This is the first committed step in tetrapyrrole biosynthesis. Two such ALA molecules condense to form the monopyrrole porphobilinogen (PBG):

$$
\begin{aligned}
& \text { Glycine ALA PBG } \\
& +>\rightarrow \text { synthase } \rightarrow \text { ALA } \rightarrow \text { synthetase } \rightarrow \text { PBG } \\
& \text { Succinyl CoA } \times 2 \\
& \forall \mathrm{CO}_{2}
\end{aligned}
$$

ALA was first shown to be an intermediate in porphyrin synthesis by Shemin and Russell ${ }^{26}$; it is formed by ALA synthase (E.C.2.3.1.37) by avian and mammalian erythrocytes, bone-marrow cells, and liver, by yeast, bacteria, and insects (see review by Granick and Beale ${ }^{27}$ ). It was also shown in a photosynthetic bacterium Rhodopseudomonas sphaeroides, ${ }^{28}$ where its activity was found to be greatest at times of maximum bacteriochlorophyll synthesis. ${ }^{29}$

The enzyme ALA synthase has not been unequivocally demonstrated in higher plants. This much debated topic was recently reviewed by Porra and Grimme ${ }^{30}$ and Beale. ${ }^{31}$ No enzyme has been described from plants which could account for the rate of 
synthesis of chlorophyll in actively greening tissues. ${ }^{32}$ Trace activities of ALA synthase have been reported in nitrogen-starved green algae, ${ }^{33}$ in cold stored potato peelings, ${ }^{34}$ and in soya bean callus under conditions where chlorophyll synthesis was minimal or repressed. ${ }^{35}$ An alternative biosynthetic pathway has been shown to exist ${ }^{3136}$ which involves the conversion of glutamate or glutamine to ALA with the original 5-carbon skeleton intact. The precise mechanism for this conversion is uncertain. ${ }^{30} \mathbf{3 1}$

It has been known for some time ${ }^{37}$ that the ALA synthesising system in plants, has, like that of animals, a short half-life. The ALA synthase in animals is located in the mitochondrial matrix. ${ }^{25}$ The location of the ALA-forming system in plants is not known though there is some evidence (for example Kannangara and Gough ${ }^{32}$ ) that $\alpha$-oxoglutarate-derived ALA may be synthesised in the isolated chloroplast. It has been postulated that plants may have two ALA-forming systems. ${ }^{31} 38$ One such system, the classical ALA synthase system, may operate in the mitochondria in the absence of light, while a quantitatively more important system utilising a glutamate derivative may be present in the chloroplast, functioning in chlorophyll synthesis. Some support for these suggestions has been provided by the examples quoted above of plant ALA synthase activity from tissue synthesising little or no chlorophyll, operating perhaps, as in animals, with the mitochondrial enzyme. Interestingly, Klein and Senger ${ }^{39}$ detected both a 'classical' ALA-synthase enzyme and a second ALA-forming mechanism in the same cells of an algal mutant. On balance, it appears that plants have evolved a separate mechanism for the synthesis of their porphyrins, but whether this separate mechanism is in addition to or replaces the mammalian ALA synthase is not known with certainty.

The enzymatic condensation of two molecules of ALA to form porphobilinogen (PBG) is well characterised. The soluble enzyme involved, PBG synthase (E.C.4.2.1.24), is present in mammalian and avian cells, fungi, bacteria, algae, and higher plants. ${ }^{25}$ First observed in avian erythrocytes, ${ }^{40}$ it has subsequently been found that the enzymes from different organisms have different co-factor requirements; potassium in some photosynthetic bacteria, zinc in mammalian erythrocytes, and magnesium or manganese in higher plants. However, the molecular weight of the enzyme (subunit mass about 35000 ) appears to be similar in all organisms. The enzyme is present in extraplastidic fractions in plants, ${ }^{41}$ but there is uncertainty as to the location of the enzyme within the plastids, whether soluble or bound to membranes.

Four molecules of porphobilinogen condense to form the first porphyrinogen in a two-step reaction involving the co-operation of the enzyme porphobilinogen deaminase (also known as uroporphyrinogen I synthase, E.C. 4.3.1.8.) and uroporphyrinogen III co-synthase. A review describing these steps has been provided by Battersby and McDonald. ${ }^{42}$ In this complex sequence of condensations there are a number of details to be cleared up. ${ }^{27}$ However, the basic mechanism involves the polymerisation of four PBG units by the deaminase to form a transient intermediate, which in the absence of co-synthase forms uroporphyrinogen $I$, but in the presence of co-synthase forms isomer III, this being the normal product. The evidence suggests that essentially the same mechanism exists in human erythrocytes as in higher plants. ${ }^{27}$ The two enzymes are present only in the cytosol in animals but the precise location in plants has yet to be shown clearly, though one location must be within the plastids.

Uroporphyrinogen III is a substrate for at least three separate pathways:

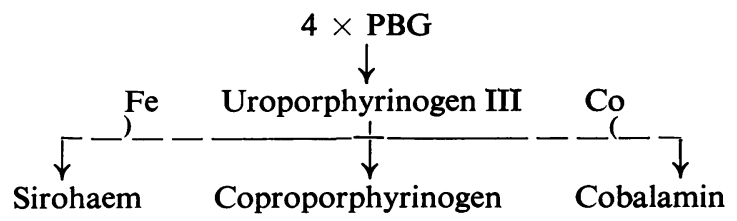

Sirohaem is structurally closely related to uroporphyrinogen (fig 4). Its relationship to uroporphyrinogen and its function in reducing environments has attracted considerable interest as a possible primitive cytochrome (see Granick and Beale ${ }^{27}$ and below). Sirohaem is the prosthetic group of sulphite reductases in several bacteria and fungi and nitrate reductases in fungi and higher plants. ${ }^{43-45}$

The second compound closely related to uroporphyrinogen III is cobalamin or vitamin $B_{12}$. The biosynthetic pathway and its unresolved problems have been discussed ${ }^{46}$ with further information provided by Horig et al. ${ }^{47}$ The conversion of uroporphyrinogen III to the intermediate cobyrinic acid involves cobalt insertion, and no less than seven methylation steps and the elimination of the $\delta$-meso carbon. ${ }^{46}$ The remaining steps involve seven amidations of the acidic peripheral groups, bonding of deoxyadenosine to the cobalt atom, and incorporation of dimethylbenzimidazole and ribose-5-phosphate. The final structure has been described as the most complex non-polymeric biomolecule. ${ }^{27}$ Vitamin $B_{12}$ is synthesised by a wide range of prokaryotes, including the reportedly haemless anaerobe Clostridium tetanomorphum, photosynthetic bacteria, blue-green algae, and the nitrogen fixing bacterium Rhizobium in higher plant root-nodules.

The third and principal pathway for uroporphyrinogen III utilisation is in the formation of the major 


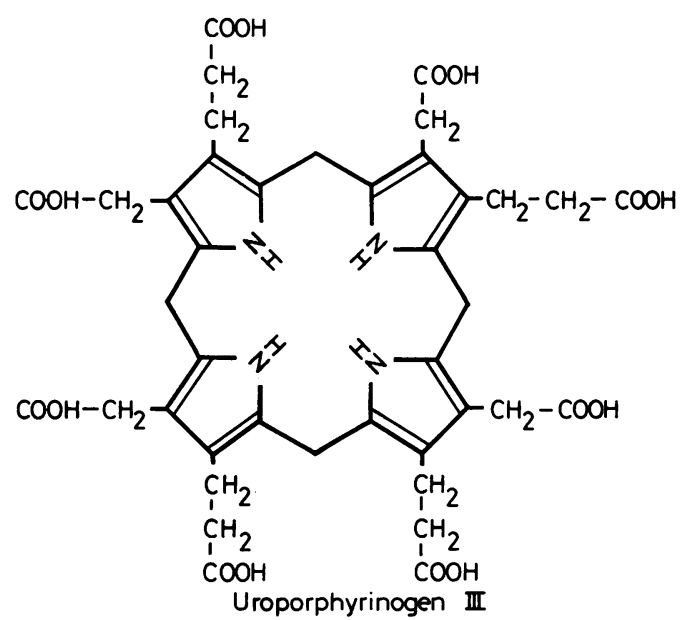

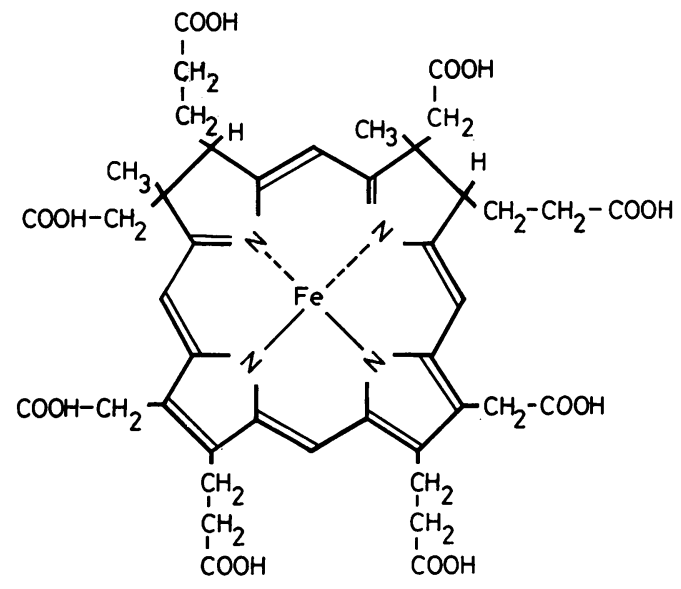

Sirohaem (proposed)

FIG 4 Structure of uroporphyrinogen III, a porphyrin precursor, and of sirohaem, the prosthetic group of a possible primitive cytochrome.

metalloporphyrins, including haems and chlorophylls. In a series of uroporphyrinogen modifications, four carboxyl carbons are removed from the acetic acid groups, one from each ring, by the enzyme uroporphyrinogen decarboxylase [E.C.4.1.1.37] to form the intermediate coproporphyrinogen $\mathrm{III} .^{48}$ The enzyme has been detected in a wide range of organisms including animals, ${ }^{49}$ photosynthetic bacteria, ${ }^{50}$ and green algae. ${ }^{51}$ While detailed comparisons are incomplete it appears that the enzyme is present in the cytosol in higher plants and in animals ${ }^{25}$ with an additional enzyme, perhaps, in the chloroplast. The product, coproporphyrinogen isomer III, does not normally accumulate. It may be deposited in avian egg shells, and in millipedes it may be chelated with copper as an integument pigment. In planarians coproporphyrin (and uroporphyrin) deposits have been implicated in phototactic responses. ${ }^{10}$

The conversion of coproporphyrinogen III to harderoporphyrinogen and then to protoporphyrinogen IX involves the enzyme coproporphyrinogen oxidase [E.C.1.3.3.3.]. The first step in the conversion involves decarboxylation of the propionate group at position 2 to a vinyl residue giving enzymebound harderoporphyrinogen. Harderoporphyrin has been isolated from the Harderian gland of the rat, and is present in small amounts in bile and bone marrow, ${ }^{52}$ and in photosynthetic Euglena. ${ }^{53}$ An interesting point is that the oxidation of the vinyl group of harderoporphyrinogen to a formyl group, and decarboxylation of the propionate at position 4 to a vinyl group, would give rise to the porphyrinogen corresponding to compound haem $s$ (or chlorocruorin). Haem $s$ acts in place of haemoglobin in several polychaete worm families (see above). Harderoporphyrinogen itself does not normally accumulate in tissue, but is a transient intermediate bound to the coproporphyrinogen oxidase enzyme, where it may undergo a rapid rotation in situ so that the second propionate group (position 4) is decarboxylated to a vinyl group. ${ }^{54}$ The product, protoporphyrinogen, may undergo spontaneous oxidation to protoporphyrin IX, or a specific enzyme (protoporphyrinogen dehydrogenase) may control this step. ${ }^{55}$ Such an enzyme has been found in several organisms including yeast and mammalian mitochondria. Certainly the substrate for iron insertion, in the final step in protohaem (haem $b$ ) synthesis, is protoporphyrin not protoporphyrinogen.

Protoporphyrin IX is, in one sense, the key compound in porphyrin metabolism. It is the direct or indirect precursor of the major haem compounds including haemoglobin, myoglobin, cytochromes $a$, $b, c$, and peroxidases and catalase, as well as the chlorophylls, and of bacteriochlorophyll in photosynthetic organisms (bacteriocholorophylls $c$ and $d$ may be exceptions, see Jones ${ }^{15}$ ). In healthy tissue protoporphyrin IX is present in trace amounts only. Treatment by iron starvation, or porphyria-inducing drugs, can lead to its accumulation in mammals, birds, fungi, plants, and bacteria. In all cases, throughout biological systems, only isomer IX is found.

Ferrochelatase [E.C.4.99.1.1.] is a membrane- $\underset{<}{2}$ bound enzyme catalysing the insertion of iron $\left(\mathrm{Fe}^{2+}\right)$ into protoporphyrin IX, yielding protohaem (haem b). Protohaem does not appear to accumulate in cells. Granick and Beale ${ }^{27}$ believe it is usual to find haem bound in the ratio 1 haem : 1 apoprotein, implying a close regulation of apoprotein synthesis with haem formation, and experimental evidence for 
haem in controlling globin synthesis is now available. In fresh lysates of rabbit reticulocytes, globin synthesis continues at a maximal linear rate for several minutes before ceasing abruptly in the absence of haem. Haem inhibits the activity of a protein kinase which in turn is an inhibitor of the initiation of protein synthesis. Exogenous haem inhibition of the kinase permits globin production to be maintained. ${ }^{56} 57$

Apart from haem $b$ synthesis the biosynthetic pathways for other haem compounds is less well known. Colleran and Jones ${ }^{58}$ showed that the haemrequiring slime mould Physarum polycephalum used protohaem, not protoporphyrin IX, in the formation of cytochrome $c$. Sinclair et $a l^{59}$ showed the conversion of protohaem to haem $a$ in a Staphylococcus mutant and similar results have been obtained with haem-requiring yeast mutant. ${ }^{60}$ It is presumed, though without conclusive evidence, that all cytochrome haems are synthesised from modifications of protohaem rather than directly from protoporphyrin IX.

The pathway leading to magnesium protoporphyrins is not clearly established. There is no unequivocal proof for a magnesium chelatase activity in extracts of either plants or photosynthetic bacteria. Evidence from mutants suggests that protoporphyrin IX is the substrate for magnesium chelation. The presumed product, Mg-protoporphyrin, undergoes esterification of the propionate group at position 6 . The methyl donor is S-adenosyl methionine in a reaction catalysed by a methyltransferase [E.C. 2.1.1.11.].

The subsequent steps from $\mathrm{Mg}$-protoporphyrin monomethyl ester to protochlorophyllide have not yet been defined. The most likely sequence appears to be that suggested by Griffiths and Jones ${ }^{61}$ and involves the following reactions.

(1) The esterified propionate group at position 6 undergoss dehydrogenation, hydration, and oxidation to yield a $\beta$-oxo group.

(2) This modified propionate group is attached to the $\gamma$-meso bridge carbon to form the cyclopentane ring $\mathrm{E}$. The product, $\mathrm{Mg}$-2,4-divinyl phaeoporphyrin $a_{5}$ monomethyl ester, has been detected in photosynthetic bacteria ${ }^{62}$ and in the seed coat of marrow. ${ }^{63}$

(3) Reduction of the vinyl group at position 4 to ethyl forms protochlorophyllide.

In most of the lower plants protochlorophyllide is rarely detected. Thus, while higher plants (for example grasses) remain yellow if deprived of light, pine seedlings, mosses, and seaweeds grow green (or brown) with or without light. In higher plants (the
Angiosperms), the conversion of protochlorophyllide (a porphyrin) to chlorophyllide (a chlorin) involves the reduction of the carbon-carbon bond at positions 7 and 8 in an NADPH-light dependent reaction by the enzyme protochlorophyllide reductase. ${ }^{64}$

The insertion of chlorophyllide $a$ into the chloroplast membrane requires the conversion of chlorophyllide to chlorophyll.65 The esterification of chlorophyllide with a long chain fatty alcohol transforms the slightly polar precursor into a lipid-membrane soluble end-product. The enzyme chlorophyllase [E.C.3.1.1.14.] may catalyse this esterification. The consequence is a loss of polar solubility and the early moments following chlorophyll formation are usually associated with changes in absorption spectra linked probably to successive rearrangements of the cholorophyll mclecules within membranes and their association with specific proteins and lipids. The membranes with their arrays of chlorophylls and other pigments are called thylakoids and are the physical location of the photochemical acts of photosynthesis.

The second chlorophyll of higher plants, chlorophyll $b$, is likely to be formed from chlorophyll $a$. Shlyk and his associates ${ }^{66}$ have reviewed much of this evidence.

Bacteriochlorophyll $a$ is probably derived from chlorophyllide $a$ in a series of reactions. The structure of the other bacteriochlorophylls is established but little is known of the biosynthetic pathways.

Just as haemoglobins and indeed all other haem proteins are associations of haem and protein, the chlorophylls are also associated with various proteins within the lipid membrane. Some six or seven chlorophyll-protein complexes have been partially characterised, with molecular weights ranging from 8000 to 70000 . One chlorophyllprotein complex contains about 20 chlorophyll $a$ molecules (and one carotenoid); another complex which has been crystallised has been shown to contain seven chlorophyll molecules on a single polypeptide chain. ${ }^{67}$

There is a considerable amount of restructuring of the photosynthetic apparatus in the green plant during the first few hours of exposure to light, whether as a seedling or as a plant initially grown in the dark. The restructuring involves formation of discoid membranous structures known as thylakoids within which the chlorophylls are sited. The thylakoids, present usually as aggregates or grana, are surrounded by an aqueous stroma limited by a double layered envelope, the whole forming the chloroplast. The processes concerned with the biophysical and chemical changes linked to the formation of a functional photosynthetic unit are complex. The changes include the synthesis of sulpholipids and 
galactolipids and additional amounts of a special c-type cytochrome (known as cytochrome $f$ ), $b$ cytochromes, carotenoids, plastocyanin and plastoquinones.

\section{Function of chlorophyll-protein complexes and haemoglobin}

Neither protohaem nor the chlorophylls are found in cells in any appreciable concentration in the free form; they are invariably complexed to proteins. ${ }^{68}$ The structure of the protohaem complex, haemoglobin, is of course well known. In mammals it is a tetramer consisting normally of two pairs of unlike polypeptide globin chains ( $\alpha$ - and $\beta$-chains), each of which contains a protohaem molecule constantly maintained in the ferrous state. Each haem is coordinated to a histidine nitrogen of a globin chain which is folded so that the haem groups lie in clefts on the surface of the haemoglobin molecule approximately equidistant from each other. ${ }^{69}$ Although one side of the iron atom of haem is co-ordinated to the imidazole of histidine, the other side is free and can bind a molecule of oxygen forming oxyhaemoglobin. It is believed that on binding to oxygen the atomic radius of the haem iron is diminished sufficiently to allow it to move into the plane of the porphyrin ring; its location in deoxyhaemoglobin is displaced out of the plane by $0.06 \mathrm{~nm}$. As the iron of the haem moves, it pulls its co-ordinated histidine with it, causing a whole series of changes in tertiary structure and breaking salt bridges and hydrogen bonds. The effect is to change the configuration of the molecule so that oxygen binds more readily to haemoglobin once one haem group is oxygenated, so a plot of oxygen saturation of haemoglobin versus oxygen tension is sigmoidal. In contrast, in myoglobin, which is a monomer, no such sub-unit co-operativity is possible and the oxygen binding curve is hyperbolic (fig 5). The details of these mechanisms are described in most modern textbooks of biochemistry and will not be covered here. Suffice it to say that the iron in the centre of the tetrapyrrole ring plays a crucial role in the function of haemoglobin and, indeed, in the function of all haem proteins. It is concerned in binding the haem to the appropriate protein and in binding and releasing oxygen. In the case of the cytochromes the iron is concerned in accepting and donating electrons and itself undergoes reversible changes from the ferrous to the ferric state.

Chlorophyll-protein complexes have two separate but closely related functions, both concerned with the absorption of light energy and its use in driving a variety of redox reactions which lead to the synthesis of ATP and assimilation of $\mathrm{CO}_{2}$. In order to participate in these reactions chlorophylls (or bacterio-

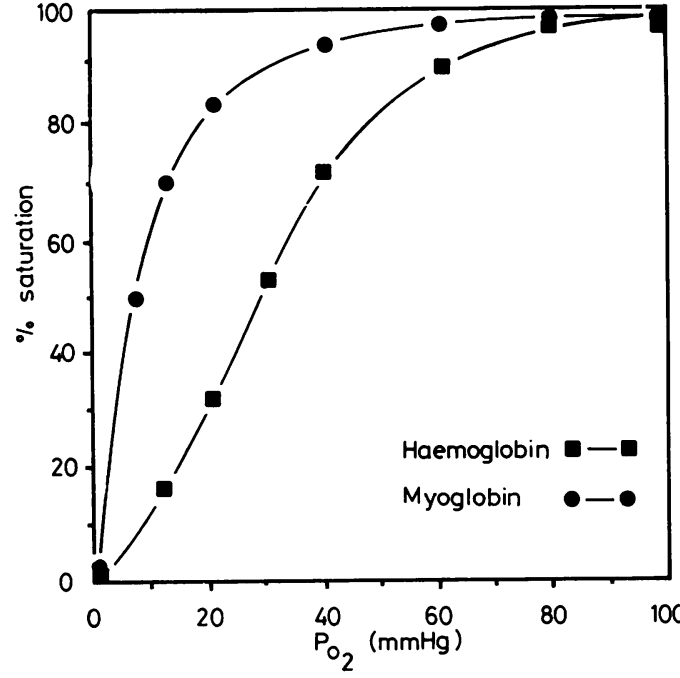

FIG 5 Saturation of haemoglobin $\square$ and myoglobin - - exposed to varying partial pressures of oxygen.

chlorophylls) must be complexed with protein, although the structure of these proteins and the nature of their binding to the chlorophylls is far from clear. The function of the first group of chlorophyll-proteins is to absorb light energy and to trans- $\mathbb{Q}$ fer the energy to the second smaller group of $\overrightarrow{\vec{F}}$ chlorophyll molecules which, when excited by this $\frac{0}{3}$ light energy, eject an electron which reduces a primary acceptor, leaving behind oxidised chlorophyll. The transfer of the electron is organised across the photosynthetic membrane so that this primary charge separation is stabilised, and an array of $\dot{0}$ electron carriers converts this form of conserved 3 . energy into the free energy of the ATP/ADP couple 8 (by mechanisms described by Mitchell $^{70}$ ) and the $₹$ redox potential of reduced NAD or NADP. 을 Chlorophyll thus functions either in light-harvesting protein complexes or in the reaction centre protein complexes.

A representation of the photosynthetic electron $\widetilde{\sigma}$ transport system of higher plants is given in fig $6 . \mathrm{N}$ This shows the two reaction centres characteristic of N the chloroplast membrane, photosystems I and II $O$ (PSI and PSII). The reducing electron lost from the excited reaction centre of PSI passes on eventually to NADP and is available for the reduction of $\mathrm{CO}_{2} \stackrel{\infty}{?}$ In the oxidised reaction centre chlorophyll (positive hole), the redox state of the central magnesium is unchanged and the electron is lost from the $\mathbb{\mathbb { Q }}$ $\pi$-electron system. It is re-reduced by an electron $\bar{\nabla}$ supplied by the excitation of the second reaction 


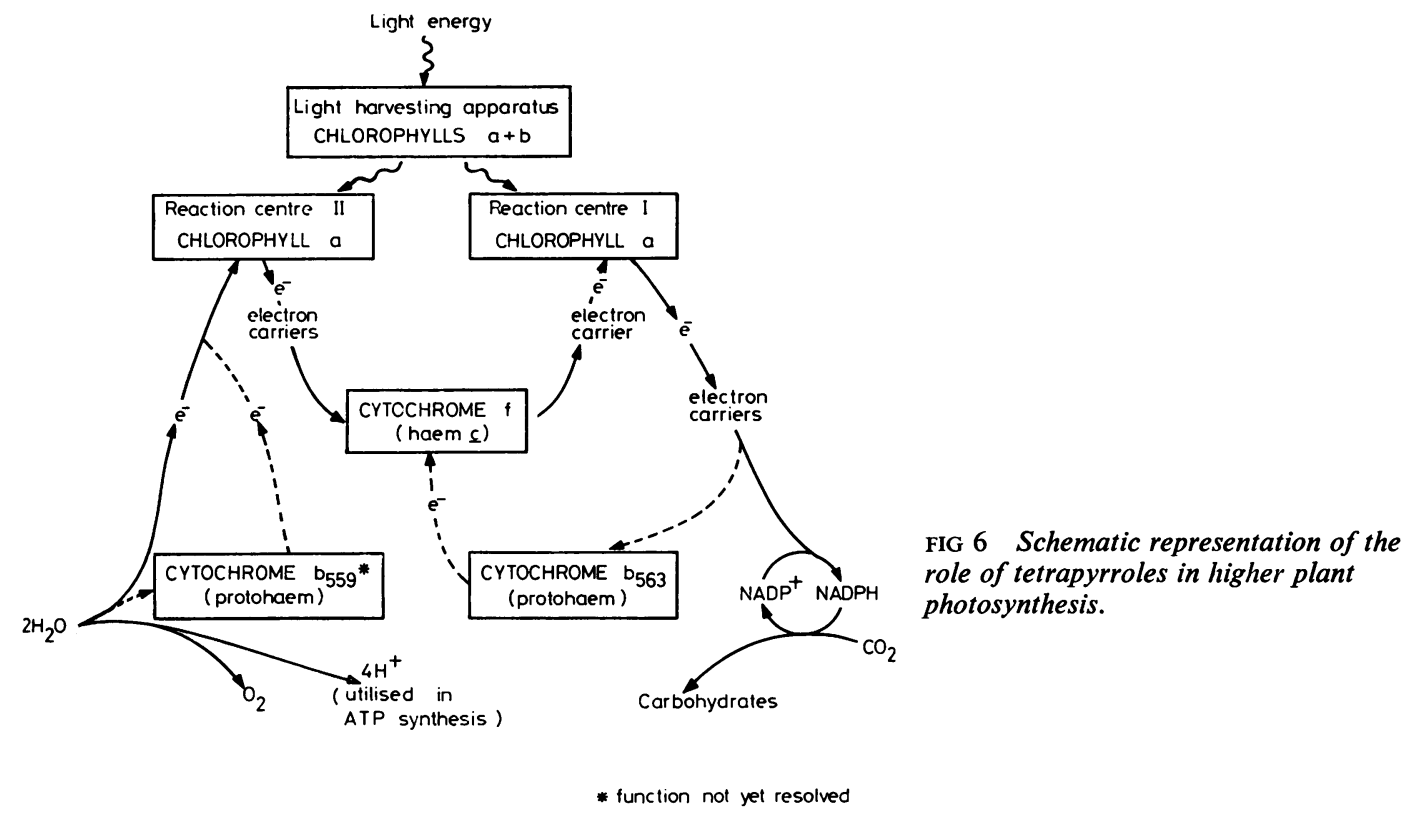

centre, PSII. The two reaction centres are connected by a chain of electron transport carriers (plastoquinones, cytochrome $f$, and the copper protein plastocyanin) which mediate this electron transfer. The oxidised PSII is itself re-reduced by electrons derived from the enzymic splitting of water:

$$
2 \mathrm{H}_{2} \mathrm{O}-\ldots \mathrm{O}_{2}+4 \mathrm{H}^{+}+4 \mathrm{e}^{-} \text {. }
$$

Oxygen is evolved as a by-product and the protons serve to provide part of the proton motive force used in ATP synthesis, as described by Mitchell. ${ }^{70}$

The chlorophyll-protein complexes involved in green plant photosynthesis have been partly purified. The complex corresponding to the PSI reaction centre has a molecular weight of about $110 \mathrm{kD}$ composed of three sub-units of roughly equal size, with about 40 chlorophyll $a$ molecules per reaction centre. No chlorophyll $b$ is present. The lightharvesting complex has a molecular weight of about $35 \mathrm{kD}$, contains three chlorophyll $a$ molecules and three chlorophyll $b$ molecules per mole, ${ }^{71}$ and accounts for about $50 \%$ of the total chlorophyll present. Purification of the PSII reaction centre is less advanced and it is not so well characterised.

Reaction centres from photosynthetic bacteria have been extensively purified and have given much information about the mechanism of photosynthesis. They are smaller than green plant reaction centres (molecular weight around $70 \mathrm{kD}$ ) but like them they are extracted from membranes with the use of detergent. Usually they are composed of three subunits and contain four bacteriochlorophylls, two bacteriophaephytins (that is bacteriochlorophylls lacking magnesium), one iron atom, and two bound quinones. Two of the bacteriochlorophylls are in close association (the 'special pair' or dimer) and function as the primary photochemical electron donor. One of the two bacteriophaeophytins is the primary electron acceptor; that is, the primary, very rapid, charge separation occurs between these two. The electron is then further transferred to a bound quinone which is closely associated with the iron atom. There is reasonable evidence from EPR spectroscopy that a similar 'special pair' of chlorophyll $a$ molecules is present in the PSI reaction centre of higher plants although there is no evidence for the presence of a phaeophytin or a quinone in this reaction centre.

Photosynthetic bacteria do not catalyse a watersplitting reaction of the type associated with PSII of green plants. When an electron is lost from the reaction centre and donated eventually perhaps to NAD, it is replaced, not from a second light reaction, but by electrons donated from substrates present in the environment. These may be organic materials, such as succinate or glutamate, or inorganic sulphur compounds, such as sulphide or thiosulphate. These donors are connected to the oxidised bacterial reaction centre by a chain of electron transport components, including quinones and cytochromes. ${ }^{72}$ 
The membranes of photosynthetic bacteria usually also contain light-harvesting pigment-protein complexes, two of which have been purified. They are named $B_{\mathbf{8 5 0}}$ and $B_{\mathbf{8 7 0}}$, where the postscript numbers indicate the wavelength maxima of their principal absorption bands. The $\mathrm{B}_{850}$ complex contains three bacteriochlorophylls per $20 \mathrm{kD}$ sub-unit, and the $B_{870}$ sub-unit two bacteriochlorophylls per $20 \mathrm{kD}$ sub-unit (see Cogdell and Thornber ${ }^{73}$ for a review). The ratio of $B_{850}$ to $B_{870}$ and to reaction centre varies with growth conditions. In general, the lower the light intensity during growth, the more lightharvesting complexes are synthesised.

There is one case in which an unusual lightharvesting pigment protein complex (isolated from the photosynthetic bacterium Prosthecochloris aestuarii) has been crystallised and its structure determined by $x$-ray diffraction. The molecule contains seven molecules of bacteriochlorophyll $a$, each on average separated from an adjacent bacteriochlorophyll by $1.2 \mathrm{~nm}$, and essentially completely surrounded by protein. ${ }^{67}$ These chlorophyll molecules are held firmly in place with little or no freedom of movement. The magnesium atoms of six of the bacteriochlorophyll molecules interact, on one side only, with the protein and there is evidence from the electron density pattern that, in some cases, the side chain ligand could be histidine, just as it is in haemoglobin. Access of a sixth ligand to the magnesium is prevented by the presence of the phytyl side chain traversing one face of the rings.

In both green plants and bacteria the bulk of the chlorophyll pigments serves a light-harvesting function. They absorb light and channel it by resonance energy transfer to the photochemical traps which, in the PSI reaction centre and bacterial reaction centres, contain the 'special pair' of pigment molecules. The special properties of the chlorophylls in vivo, the positions of their absorption maxima, and their photochemical activity are dependent on their association with specific proteins. In this, chlorophylls and protohaem can be seen to have great similarity. Stripped of their proteins they lose their desirable properties. Their spectra change dramatically and their redox properties are quite different.

\section{Evolution}

Attempts have been made in the past to unify the evolution of haems, haemoglobin, cytochromes, and chlorophylls. $^{65}$ 74-77 The basis of these attempts has been largely speculative though with some supporting evidence. ${ }^{65}$ The postulates assume that in the course of evolution, each of the intermediates in porphyrin biosynthesis was, at one time, an end product of metabolic advantage to the cell. Subse- $\overparen{D}$ quent modifications to the end product improved its properties and led to abandonment of the direct use $\stackrel{5}{9}$ of intermediates which now are unable to function 0 per se in primary metabolism. The evolutionary 흘 process therefore represents a progressive elaboration $\frac{\bar{c}}{\frac{7}{7}}$ of mechanisms for carrying out the original primitive $\Phi$ functions of porphyrins in a more efficient manner. ${ }^{75}$ A problem arises in attempting to link today's end products (haems and chlorophylls) with the functions of porphyrins in the primitive environmental $\overrightarrow{\vec{\omega}}$ conditions of early life. This problem has been $\stackrel{\omega}{\sigma}$ discussed by Granick ${ }^{75}$ and Mauzerall ${ }^{77}$ and several hypotheses have been made.

Granick $^{75}$ has shown that the monopyrrole PBG, $\vec{v}$ when heated in neutral or alkaline conditions, forms $\overrightarrow{-}$ uroporphyrinogen isomers I or III (but not isomers $\vec{\circ}$ II or IV). Such a chemical event, it is postulated, may have provided, in low concentrations, a com- $\vec{T}$ pound used to advantage in the primitive cell. $\mathbb{D}$ Genes then evolved to synthesise the porphyrin more efficiently. The first tetrapyrrole in the biosynthetic pathway is uroporphyrinogen. This compound can be oxidised to yield uroporphyrin which $\stackrel{\odot}{\varnothing}$ absorbs light, is fluorescent, and can carry out photosynthetic reactions. It can form a metal chelate to serve as a redox catalyst. ${ }^{65}$ The modifications to uroporphyrin(ogen) III that subsequently took place in all organisms would have reflected changing environmental conditions. One such $\mathbb{Q}$ change would have been the development of photo- $\overrightarrow{\vec{A}}$ synthesis and oxygen release into the atmosphere.

Mauzerall ${ }^{65}$ postulates that the change from the free porphyrin to the metalloporphyrin initiated the development of efficient photosynthesis. Mg-porphyrins, in light-induced excited states, form strongly reducing agents; coupling reducing reactions with $\dot{\sigma}$ electron donation from water-splitting (resulting in 3 electron, proton, and oxygen release) led ultimately $\delta$ to modern photosynthesis. Increasing oxygen levels in the environment of the metalloporphyrin would 을 lead to the quenching of the photo-excited state of chlorophyll. However, in a lipid environment the photo-pigment would be protected sufficiently to allow electron ejection and so highly hydrophobic o metalloporphyrins would be favoured. Haem por- $N$ phyrins, as cytochromes, are able to act as electron $\underset{\mathrm{C}}{\mathrm{N}}$ acceptors and donors and may therefore have evolved together with photosynthesis.

Iron porphyrins are relatively photo-inactive but $\stackrel{\odot}{\ulcorner}$ may readily complex oxygen. The metabolic advantage gained from exploiting this property would provide for the development of haemoglobin (or a myoglobin precursor) in oxygen transport, storage, $\mathbb{D}$ and release. When linked to cytochrome oxidase $\vec{D}$ these would provide the essential components of 
respiration in higher organisms. Such a respiratory function presumably arose after the development of a mechanism for the continuous production of oxygen (photosynthesis) to complete the mechanism of modern respiration.

Porphyrins function in a number of different ways in biological systems, including oxygen carrying and storage, light energy transfer, and light induced electron ejection. Even more variation occurs in porphyrin structure, with many side group modifications and a limited number of central metal ion substitutions. Despite these variations in structure and function, the evidence suggests that porphyrin biosynthesis is essentially similar in all biological systems. While there is a possible difference in the synthesis of the porphyrin precursor 5-amino laevulinic acid in plants from animals and bacteria, the subsequent steps in the formation of protoporphyrin IX are similar in all organisms. The similarity is sufficiently great to support the contention that porphyrins have arisen in the course of evolution from a common origin. The variation in function between the two great families, the haems and the chlorophylls, is perhaps the result of the adaptability of the porphyrin structure to changing biochemical requirements.

GAFH acknowledges financial support from the Medical Research Council and OTGJ from the Science Research Council.

\section{References}

1 Verdeil F, 1844. Quoted by Aranoff S. The chlorophyllsan introductory survey. In: Vernon LP, Seely GR, eds. The chlorophylls. London: Academic Press, 1966:1-20.

2 Hoppe-Seyler F, 1880. Quoted by Aranoff S. The chlorophylls-an introductory survey. In: Vernon LP, Seely GR, eds. The chlorophylls. London: Academic Press, 1966: 1-20.

3 McMunn CA. On myohaematin, an intrinsic musclepigment of vertebrates and invertebrates, on histohaematin, and on the spectrum of the super-renal bodies. J Physiol 1884;5:24.

4 Nencki M, Zaleski J. Uber die reductions producte des hamins durch jodwasserstoff und phosphoniumjodid und uber die construction des hamins und seiner derivate. Ber Dtsch Chem Ges 1901;34:997-1010.

5 Nencki M, Marchlewski L. Zur chemie des chlorophylls. Abbau des phyllocyanins zum hamopyrrol. Ber Dtsch Chem Ges 1901;34:1687-90.

6 Willstätter R. Untersuchungen uber chlorophyll XVIII. Uber die reduktion des chlorophylls I. Liebigs Ann Chem $1911 ; 385: 188-225$.

7 Fischer H, Stern A. In: Die Chemi des Pyrrols II. Leipzig: Akademische Verlagsgesellschaft, 1940.

8 Hodgson GW. Geochemistry of porphyrins-reactions during diagenesis. Ann NY Acad Sci 1973;206:670-84.

9 Hodgkin DC. Vitamin $\mathrm{B}_{12}$ and the porphyrins. Fed Proc $1964 ; 23: 592-8$.

10 Kennedy GY. Porphyrins in invertebrates. Ann NY Acad Sci 1975;244:662-79.
11 Rudd JT. Vertebrates without erythrocytes and blood pigments. Nature 1954;173:848-50.

12 Cutting JA, Schulman HM. The control of heme synthesis in soybean root nodules. Biochim Biophys Acta 1972;261: 321-7.

13 Kennedy GY. Porphyrins: structure, distribution and metabolism. In: Florkin M, Mason HS, eds. Comparative biochemistry. vol IV-B. London: Academic Press, 1962: $557-614$

14 Hendry GAF, Stobart AK. Haem and chlorophyll formation in etiolated and greening leaves of barley. Phytochem 1977;16:1545-8.

15 Jones OTG. Biosynthesis of porphyrins, hemes and chlorophylls. In: Clayton RK, Sistrom WR, eds. The photosynthetic bacteria. New York: Plenum, 1978: 751-78.

16 Bogorad L. Phycobiliproteins and complementary chromatic adaptation. Annu Rev Pl Physiol 1975;26:369401.

17 Rudiger W. Ueber die Abwehrfarbstoffe von AplysiaArten. II. Die Struktur von Aplysiaviolin. Hoppe Seylers Z Physiol Chem 1967;348:1554.

18 Rudiger W, Klose W, Vuillaume M, Barbier M. On the structure of pterobilin, the blue pigment of Pieris brassicae. Experientia 1968;24:1000.

19 Chapman DJ, Cole WJ, Siegelman HW. Chromophores of allophycocyanin and R-phycocyanin. Biochem $J$ 1967;105:903-5.

20 Grombein S, Rudiger W, Zimmerman H. The structure of the phytochrome chromophore in both photoreversible forms. Hoppe Seylers $Z$ Physiol Chem 1975;356:1709-14.

21 O'Carra P, Colleran E. Separation and identification of isomeric deuterobiliverdins and mesobiliverdins. J Chromatogr 1975;108:212-5.

22 Maines MH. Heme metabolism: factors affecting the in vivo oxidation of heme. In: Gordon AS, Silber R, LoBue J, eds. The year in hematology. New York: Plenum, 1977:1-45.

23 Sanger JE. Quantitative investigations of leaf pigments from their inception in buds through autumn coloration to decomposition in falling leaves. Ecology $1971 ; 52: 1075$ 89.

24 Smith KM. 1st Tetrapyrrole Discussion Group meeting, Cardiff, 1976.

25 Bogorad L. Chlorophyll biosynthesis. In: Goodwin TW, ed. Chemistry and biochemistry of plant pigments. vol 1, 2nd ed. London: Academic Press, 1976:64-148.

26 Shemin D, Russell CS. $\delta$-aminolaevulinic acid, its role in the biosynthesis of porphyrins and purines. J Am Chem Soc $1953 ; 75: 4873-4$.

27 Granick S, Beale SI. Hemes, chlorophylls and related compounds; biosynthesis and metabolic regulation. $A d v$ Enzymol 1978;46:33-203.

28 Kikuchi G, Kumar A, Talmage P, Shemin D. The enzymatic synthesis of $\delta$-amino laevulinic acid. $J$ Biol Chem 1958;233:1214-9.

29 Lascelles J. Regulation of haem and chlorophyll synthesis. In: Goodwin TE, ed. Porphyrins and related compounds. London: Academic Press, 1968:49-60.

30 Porra RJ, Grimme LH. Tetrapyrrole biosynthesis in algae and higher plants. Int J Biochem 1978;9:883-6.

31 Beale SI. $\delta$-amino laevulinic acid: its biosynthesis, regulation and role in plastid development. Annu Rev Pl Physiol 1978;29:95-120.

32 Kannangara CG, Gough SP. Synthesis of $\delta$-aminolaevulinic acid and chlorophyll by isolated chloroplasts. Carlsberg Res Commun 1977;42:441-57.

33 Porra RJ, Grimme LH. Chlorophyll synthesis and intracellular fluctuation of $\delta$-amino laevulinic acid formation 
during the regreening of nitrogen deficient Chlorella fusca. Arch Biochem Biophys 1974;164:115-23.

34 Ramaswamy NK, Nair PM. $\delta$-aminolaevulinic acid from cold-stored potatoes. Biochem Biophys Acta 1973;293: 269-77.

35 Wider de Xifra EA, Batlle AMC, Tigier HA. $\delta$-aminolaevulinic acid synthetase in extracts of cultured soybean cells. Biochim Biophys Acta 1971 ;235:511-7.

36 Beale SI. The biosynthesis of $\delta$-amino laevulinic acid in plants. Philos Trans $R$ Soc Lond (Biol) 1976;273:99-108.

37 Nadler K, Granick S. Controls on chlorophyll synthesis in barley. Plant Physiol 1970;46:240-6.

38 Hendry GAF, Stobart AK. Effect of 2,2'-bipyridyl on porphyrin synthesis in etiolated and light-treated barley leaves. Phytochem 1978;17:671-4.

39 Klein O, Senger H. Biosynthetic pathways to $\delta$-amino laevulinic acid induced by blue light in the pigment mutant C-2A of Scenedesmus obliquus. Photochem Photobiol 1978;27:203-8.

40 Dresel EIB, Falk JE. Conversion of $\delta$-amino laevulinic acid to porphobilinogen in a tissue system. Nature 1953; 172:1185.

41 Stobart AK, Thomas DR. $\delta$-aminolaevulinic acid dehydratase in tissue cultures of Kalanchoe crenata. Phytochem 1968;7:1313-20.

42 Battersby AR, McDonald E. Biosynthesis of porphyrin and corrins. Philos Trans $R$ Soc Lond (Biol) 1976;273: 161-80.

43 Murphy MJ, Siegel LM, Kamin H, Rosenthal D. Reduced nicotinamide adenine dinucleotide phosphatesulphite reductase of Enterobacteria. J Biol Chem 1973; 248:2801-14.

44 Vega JM, Garrett RH, Siegel LM. Sirohaem: a prosthetic group of Neurospor a crassa assimilatory nitrite reductase. J Biol Chem 1975;250:7980-9.

45 Hucklesby DP, James DM, Banwell MJ, Hewitt EJ. Properties of nitrite reductase from Cucurbita pepo. Phytochem 1976;15:599-603.

46 Scott AI. The biosynthesis of vitamin $B_{12}$. Philos Trans $R$ Soc Lond (Biol) 1976; 273:303-18.

47 Horig JA, Renz P, Heckman G. $\left(5-{ }^{15} \mathrm{~N}\right)$ riboflavin as precursor in the biosynthesis of the 5,6-dimethylbenzimidazole moiety of vitamin $B_{12}$. J Biol Chem 1978;253: $7410-4$.

48 Granick S, Mauzerall D. Porphyrin biosynthesis in erythrocytes. II. Enzymes converting $\delta$-amino laevulinic acid to coproporphyrinogen. $J$ Biol Chem 1958;232: 1119-40.

49 Batlle AMC, Grinstein M. Porphyrin biosynthesis. I. Studies on erythrocyte preparations. Biochim Biophys Acta $1964 ; 82: 1-12$.

50 Hoare DS, Heath H. The biosynthesis of porphyrins from porphobilinogen by Rhodopseudomonas sphaeroides. Biochem J 1959;73:379-84.

51 Bogorad L, Granick S. The enzymatic synthesis of porphyrins from porphobilinogen. Proc Natl Acad Sci USA $1953 ; 39: 1176-88$.

52 Smith SG, Belcher RV. Distribution of some possible intermediates of the haem biosynthesis. Enzyme 1974; 17:1-6.

53 Cavaleiro JAS, Kenner GW, Smith KM. Pyrroles and related compounds. XXXII. Biosynthesis of protoporphyrin IX from coproporphyrin III. J Chem Soc (Perkin I) 1974;7:1188-92.

54 Jackson AH, Elder GH, Smith SG. The metabolism of coproporphyrinogen III into protoporphyrin IX. Int $J$ Biochem 1978;9:877-82.

55 Poulson R, Polgase WJ. Enzymic conversion of protoporphyrinogen IX to protoporphyrin IX. J Biol Chem 1975;250:1269-77.
56 Legon S, Jackson RJ, Hunt T. Control of protein synthesis in reticulocyte lysates by haemin, Nature 1973;241:150-2.

57 Ranu RS, London IM, Das A, Dasgupta A, Majumdar A, Ralston R, Roy R, Gupta NK. Regulation of protein synthesis in rabbit reticulocyte-lysates by the hemeregulated protein kinase. Proc Natl Acad Sci USA 1978; $\frac{\mathrm{\sigma}}{\overline{\mathrm{S}}}$ 75:745-9.

58 Colleran FM, Jones OTG. Studies on the biosynthesis of $\vec{\nabla}$ cytochrome $c$. Biochem J 1973;134:89-96.

59 Sinclair P, White DC, Barrett J. The conversion of protoheme to heme $a$ in staphylococcus. Biochim Biophys Acta 1967;143:427-30.

60 Muller JS, Schatz G. Heme is necessary for the accum- $\overrightarrow{\vec{H}}$ mulation and assembly of cytochrome $c$ oxidase subunits $\vec{\omega}$ in Saccharomyces cerevisiae. J Biol Chem 1978;253:305-10.

61 Griffiths WT, Jones OTG. Magnesium 2,4-divinylphaeoporphyrin $a_{5}$ as a substrate for chlorophyll bio- 9 synthesis in vitro. FEBS Lett $1975 ; 50: 355-8$.

62 Jones OTG. Magnesium 2,4-divinylphaeoporphyrin $a_{5}$. monomethyl ester, a protochlorophyll-like pigment produced by $R$. sphaeroides. Biochem $J$ 1963;89:182-9.

63 Jones OTG. A protein-protochlorophyll complex obtained from the inner seed coats of Cucurbita pepo. Biochem J 1966;101:153-60.

64 Griffiths WT. Reconstitution of chlorophyllide formation 음 by isolated etioplast membranes. Biochem $J$ 1978;174: 681-92.

65 Mauzerall D. Chlorophyll and photosynthesis. Philos Trans $R$ Soc Lond (Biol) 1976;273:287-94.

66 Shlyk AA. Biosynthesis of chlorophyll b. Annu Rev Pl Physiol 1971;22:169-202.

67 Fenna RE, Matthews BW. Structure of a bacteriochlorophyll a-protein from Prosthecochloris aesturii. Brookhaven Symp Biol 1977;28:170-81.

68 Markwell JP, Thornber JP, Boggs RT. Higher plant chloroplasts: evidence that all chlorophyll exists as chlorophyll-protein complexes. Proc Natl Acad Sci USA \& 1979;76:1233-5.

69 Perutz MF. Stereochemistry of cooperative effects in haemoglobin. Nature 1970;228:726-34.

70 Mitchell P. Chemiosmotic coupling in energy transduction: a logical development of biochemical knowledge. J Bioenerg Biomembr 1972;3:5-24.

71 Thornber JP, Alberte RS, Hunter FA, Shiozaw JA, Kan KS. The organisation of chlorophyll in the plant photosynthetic unit. Brookhaven Symp Biol 1977;28: 132-48.

72 Jones OTG. Electron transport and ATP synthesis in the photosynthetic bacteria. In: Haddock BA, Hamilton WA, eds. Microbial energetics. Soc Gen Microb Symp 27. Cambridge: Cambridge University Press, 1977:151-84.

73 Cogdell RJ, Thornber JP. The preparation and characterization of different types of light-harvesting pigmentprotein complexes from some purple bacteria. $C I B A$ Found Symp 1978;61:61-79.

74 Granick S. The structural and functional relationship o between heme and chlorophyll. Harvey Lect 1949;44: N $220-45$.

75 Granick S. Evolution of heme and chlorophyll. In: $\mathcal{W}$ Bryson V, Vogel HJ, eds. Evolving genes and proteins. London: Academic Press, 1965:67-88.

76 Buettner-Janusch J, Hill RL. Evolution of hemoglobin in primates. In: Bryson V, Vogel HJ, eds. Evolving genes and \& proteins. London: Academic Press, 1965:183-201.

77 Mauzerall D. Why chlorophyll? Ann NY Acad Sci T 1973;206:483-94.

Requests for reprints to Dr G A F Hendry, Department of Biochemistry, The Medical School, University of Bristol, Bristol BS8 1TD. 